\title{
Intensive Case Study Methodology for the Analysis of Self-Help Housing Consolidation, Household Organization and Family Mobility
}

\author{
Peter M. Ward1, Edith R. Jiménez Huerta2 ${ }^{2}$ María Mercedes Di Virgilioo,4 \\ ${ }^{1}$ Department of Sociology, \& The Lyndon B. Johnson School of Public Affairs, The University of Texas at Austin, \\ Austin, USA \\ ${ }^{2}$ Departamento de Estudios Regionales, Universidad de Guadalajara, Guadalajara, Mexico \\ ${ }^{3}$ Instituto de Investigaciones Gino Germani, Universidad de Buenos Aires, Buenos Aires, Argentina \\ ${ }^{4}$ Consejo Nacional de Investigaciones Científicas y Técnicas, Buenos Aires, Argentina \\ Email: peter.ward@austin.utexas.edu, ejimenez@cucea.udg.mx, mercedes.divirgilio@gmail.com
}

Received 25 April 2014; revised 10 May 2014; accepted 1 June 2014

Copyright @ 2014 by authors and Scientific Research Publishing Inc.

This work is licensed under the Creative Commons Attribution International License (CC BY).

http://creativecommons.org/licenses/by/4.0/

cc) (i) Open Access

\begin{abstract}
The paper describes an innovative methodology developed as part of a major "mixed methods" collaborative and multidisciplinary research project across several Latin American cities. It offers a systematic "hands-on" methodology about how to conduct multi-disciplinary and team-based intensive case studies of low-income household dynamics and trajectories in self-help dwelling structures in (now) consolidated low-income settlements of Latin America. The research project describes how to collect information about family genealogies, household organization and individual member mobility, tied to materials that allow for the construction of detailed housing plans and architectonic diagrams resulting from self-building in informal settlements over a thirty-year period. The majority of the original "owner" self-builders still reside in these (now) consolidated properties, and the methodology provides for cross generational analysis of household behavior in relation to the dynamics of dwelling construction and use of space, household organization, inheritance and heirship.
\end{abstract}

\section{Keywords}

Case Study Methodology, Informal Settlements, Latin America, Dwelling Spaces, Trans-Generational Inheritance, Mobility Patterns

\section{Introduction}

Case studies are an important and widely used strategy within qualitative research that seeks to understand low

How to cite this paper: Ward, Jiménez, \& Di Virgilio (2014). Intensive Case Study Methodology for the Analysis of Self-Help Housing Consolidation, Household Organization and Family Mobility. Current Urban Studies, 2, 88-104. 
income communities and housing dynamics. In the 1960s, Oscar Lewis used "typical family case studies" to illustrate his theory of a "culture of poverty", which even at the time attracted a vitriol of criticism for being non-structural, and for being overly selective in the way in which he viewed and presented the case study materials (see Valentine, 1968; Safa, 1970; Leacock, 1971). Around the same time, other classic ethnographic case studies were leading to grounded theory that demonstrated the high levels of social organization in the so-called slums of the East End of London (Young and Willmott, 1957), life among the first and second Italian migrants of the West End of Boston (Gans, 1962), and gang culture in Chicago (Suttles, 1974). These and other scholars (for example, Portes, 1972), demonstrated the existence of high levels of "rationality" in the so-called slum that contributed to a sea-change in social constructions about the nature of the underclass, and, subsequently, led to a paradigm shift in housing programs that argued against extensive eviction and urban resettlement programs to more sensitive policies of in situ urban renovation, unlike the focus of those particular urban regeneration projects of the 1960s. A generation later, similar ethnographic and case study approaches recast this rationality and organization into what became more widely understood as social capital (Coleman, 1988; Putnam, 1993).

To fast forward another generation to the present day, and case studies remain an important part of qualitative research (Creswell, 2013; Stake, 1995): whether as a means to develop grounded theory, or to offer detailed and "thick" descriptions of life in a particular bounded setting, or as a strategy to analyze phenomena through comparative analysis. However, a number of problems arise in using case studies effectively. These include becoming lost in such detail that one cannot see the broader forest for the trees; problems of path dependency where the nature of the case itself drives the analysis and findings and belies effective interrogation of the case; problems and questions of selectivity; and the inability (or difficulty) to convincingly and effectively generalize from a single or small "N". Comparative analysis can partially overcome these problems by seeking to explore and explain differences between cases (Gilbert \& Ward 1985), but here, too, issues of selectivity remain (Ragin, 2003). Research that seeks to ensure randomness in selection may also work with case studies, but this often leads away from qualitative research into the realm of more experimental design such as random control trials, "natural" experiments and more quantitative methods, and the twain rarely meet (Dunning, 2012).

In this paper we make no attempt to reconcile those approaches except to note that many of us work "both sides of the street", and use qualitative methods generally, and case studies in particular, in order to provide deeper insights about processes that might help explain some of the findings and correlations identified in other broader multivariate data analyses. Indeed, this is the approach that we adopt in this paper, since we first conducted extensive household surveys and later used an intensive case study methodology to gain detailed insights about the nature and dynamics of household and family organization in low income settlements in Latin American cities (Ward, Jiménez, \& Di Virgilio, 2014; Latin American Housing Network [LAHN] www.lahn.utexas.org).

We argue that the methodology offered here is innovative, and differs from other case study analyses in several respects. First, our selection of cases is deliberately purposive and comprises "interesting cases" that were identified a priori, and which emerged from our contextual analysis of each city, and specifically from particular household interviews that formed part of random surveys conducted across several informal settlements in several Latin American cities. Second, each case is conducted by several researchers working together as a multidisciplinary team (sociologists, anthropologists, architects) who meet on-site two or three times with a particular family or cluster of households living on a single lot, and work intensively to gather data over several hours in order to collect the materials with which to build the case study. Third, we use several qualitative methods in combination: semi-structured and key informant interviews with various family members; the preparation of the family genealogy; trajectories of household members linked to the dwelling space and individual occupation of rooms as household members exit and enter the residence. In addition we gathered detailed measurements of room dimensions, functions, lighting, privacy and room (space) usage over time, all of which were matched to a photographic record of the current property, room usage, and any particular physical problems that we were able to identify. As well as providing insights that would inform our research into these consolidated settlements, an important goal was also to develop a case study methodology that might prove helpful to future researchers wishing to conduct similar research, either individually or as a team.

In some respects this methodology forms a "lite" version of Oscar Lewis' strategy of case study analysis (see for example Lewis, 1961; 1968), in which he used multiple interviews with family members, time budgets, participant observation, flashpoint "crisis" analysis, content analysis, etc., although in his work data collection extended over months rather than hours. Despite the flawed thinking within his theory of a culture of poverty, we believe that much can be learned from Lewis' ethnographic techniques and skills. Unlike Lewis, however, we do 
not claim that the family case studies that we analyze represent "typical case studies": they were chosen without knowing in advance whether they would be typical or not. Indeed, we were not aiming for "typicality", but rather deeper insights about social and architectonic processes. Cases were purposively selected as outliers, or as especially interesting experiences that would shed light on locally important processes to which we had been alerted during earlier surveys and ongoing phases of data collection.

The case study methodology described below takes the family or household as the unit of analysis and it allows us to examine in depth the inter-relationships between individuals and the wider social structure (Varley, 1994). Specifically the family or household unit constitutes the social group or institution that embraces the structural unit and primary relationships in the social reproduction of its members (in general terms), as well as the production and consumption of residential space (in particular). It is the principal institution that directly shapes the structure and dynamics of labor, housing, and land markets, especially in the context of informal employment and settlement patterns in which formal institutions traditionally play only a limited and indirect role. Moreover, the family and household unit is the primary level at which social networks are embedded and mobilized (González de la Rocha, 1994; Menéndez, 1992: p. 4).

\section{The Context: Consolidated Settlements in Latin America's "Innerburbs"}

The backdrop to our analysis is 1960s rapid urbanization in Latin America that led to the extensive growth of low income irregular settlements, settlements, formed by squatter invasion or by illegal subdivision (Gilbert \& Ward, 1985; UN-Habitat 2003, 2006). As the phenomenon of informal settlement became widespread, often outpacing the rate of formal urbanization, by the 1980s, self-build settlements had come to comprise between 10 - 60 percent of the built up area of many cities (Gilbert, 1996: p. 74). Today these older and now serviced and regularized settlements from the 1960s and 1970s often form part of the intermediate ring of Latin American metropolitan areas, what we call the "innerburbs", roughly equivalent to the "first suburbs" that developed in the USA between 1950-1980 (Berube, Lang, \& Katz, 2005). Rather different in Latin America is the fact that the low income first suburbs were built through self-help over time, and many of these original pioneer self-builders settled on their lots some 30 - 40 years ago and continued to live there today. Once established, there appears to be minimum outward mobility among low-income "owners" (Gilbert, 1999; Ward 2012). Given the advanced age of many owners, these dwellings and lots are now beginning to be inherited by second and third generations, some of whom already share residential space on the lot with their parents and siblings, and view eventual inheritance as the only route to their also becoming home owners.

The major comparative Latin American research project (LAHN) that informs this paper comprises a multi-disciplinary effort across eleven cities in nine countries, and target the first suburbs in order to develop a new generation of housing policies based around housing and community rehabilitation needs, rather than the more usual upgrading and regularization policies associated with recently formed informal or "irregular" settlements (www.lahn.utexas.org). Our methodology involved three phases and levels of research and data collection. First, at the city-wide level we used a common framework of analysis that included GIS and other data to define what constitutes the first suburbs or "innerburbs" in each city and which are now consolidated low income settlements that formed between 1960 and 1985. Second, we selected between two and four settlements that, $a$ priori, were broadly representative of consolidated settlements in the innerburbs of each city and which conformed to our previously agreed criteria for selection: age, size, low-income, informal, and for the most part were homes that were self-built by the families themselves. In each of these settlements we randomly applied the questionnaire survey to between 60 and 100 households (almost all were owners), and gathered data about household organization and dwelling characteristics in these settlements that could be analyzed comparatively ${ }^{1}$.

The third level and data collection phase involves the methodology described in this paper, and targets a small number of "intensive case studies" (casos a profundidad) that allowed us to develop a better understanding of the social processes in a few "interesting" cases of the previously surveyed households. The aim was to use these cases to delve more deeply into the iterations between family and household dynamics, life histories and trajectories, future expectations about ownership, and the evolution of the dwelling structure ${ }^{2}$.

In the remainder of this paper we offer a step-by-step guide to that third phase methodology. It involves an

\footnotetext{
${ }^{1}$ These redacted databases are publicly available at www.lahn.utexas.org. See also the Comparative City Data Matrix (in Excel) at the same location.

${ }^{2}$ The Guadalajara team ran a number of focus groups in which local residents and the neighbors participated.
} 
intensive case study analysis of a small number of selected families who had first been interviewed as part of the settlement and barrio surveys in 2009-2010. Selection of the cases was purposive, taking a particular aspect of household or housing dynamics that appeared to be an especially important and significant feature in colonias or barrios in that particular city. The survey protocols were developed collaboratively by network research leaders and were first applied in Monterrey and Guadalajara (Mexico), with subsequent refinement and application in Mexico City, Buenos Aires, Recife, Bogotá and Lima. Later (in 2011), a similar methodology was adopted for several cases among previously surveyed families living in self-help settlements or colonias outside of Texas' Rio Grande City (Durst \& Ward, 2014). In total, some 50+ individual case studies were built across these cities, and the following methodological strategy represents a synthesis of those experiences.

\section{The Application of an in-Depth "Interesting Cases" Methodology}

When we first began to think about designing these in-depth case studies we imagined that we would probably need to conduct at least 20 in each city. However, we quickly realized that only a much smaller number made sense if we were to be successful in achieving a meaningful interdisciplinary analysis about in depth life histories of each household, the dynamics and aspirations of household members, and the rationale for home evolution and additions as the household recast itself over time. Thus we scaled back, and ultimately ended up selecting a handful (usually six to eight cases) in each city.

\subsection{Case Study Selections and the Pre-Survey Template}

The first task was to develop a template that we would use as the basis for data collection and organization across the aforementioned cities. This common framework comprises a 13 point check list of themes to be covered starting with basic data and metadata harvested from the survey and the specific rationale for its selection. Given the space constraints of article length, and the desirability of providing illustrations of the ways in which we gathered the materials and built the final products, we are placing all figures into the side-bar folder for consultation by the reader). The Appendix to this paper (in Spanish) illustrates the template or ficha that we used. Some sections of the template were designed to be developed in all cases (e.g., the metadata, family history and family genealogy and mobility timeline, the dwelling structure measurements and build-outs), while other sections would only be developed in detail depending upon the issue that formed the primary reason for selection (remittances and investment in the home; intestacy conflicts, etc.).

\subsection{Compensation of Respondents}

In 2008, at one of our regional meetings of project leaders from each city, we debated whether or not families should be paid for their participation (one option), or should instead be compensated in a less direct way-such as a basket of foodstuffs or other essentials. Here is not the place to describe the pros and cons of each alternative, suffice to note that there was strong resistance to direct payment, and that there was general agreement that compensation should usually be in kind. In Monterrey, Guadalajara, and Buenos Aires, rather than a basket of goods, our practice was to offer two deliverables to each family: 1) a "family tree" or genealogy of the household; and 2) a series of detailed architectonic plans and sketch-ups of that household's particular dwelling and lot. The plans offered a baseline for any future extensions or housing modifications that the family might wish to make, as well as a record of the build out of their dwelling. Elsewhere (in Texas 2010 and in Mexico City, 2011), we also offered a modest payment (\$25 - \$40) to the head of household for each substantial visit, along with the promise of later returning with detailed site plans of their home ${ }^{3}$. In a context in which there was considerable unease about letting strangers into one's home, this dual commitment of cash in hand and later delivery of plans proved quite helpful in getting persuading people to participate ${ }^{4}$.

\footnotetext{
${ }^{3}$ These plans (Figure 6 \& Figure 7) even when detailed and accurate architectonically do not serve as official plans for construction permissions since the latter requires a more detailed survey of the materials and construction loadings.

${ }^{4} \mathrm{~A}$ modest payment also proved crucial in Rio Grande City, Texas, where we offered $\$ 40$ plus later plans. Although we were not always successful in gaining access to particular households, both our experience in Mexico City and Texas suggest that, especially among low income populations; some significant form of payment is both appropriate and likely to enhance successful completion of the family case study.
} 


\subsection{Fieldwork \& Multiple Visits Strategy}

Our original strategy called for a minimum of three separate visits, with the data and household profiles being built up gradually over each visit, as the team members developed a rapport with individual household members. While this remains an optimum strategy, in practice we found that it was often best to front-load as much of the basic data capture during the first visit, with later follow-up visits to cross check data, interview additional household members, and finally to deliver the products that we had promised the family as a recompense for their time and good will in meeting with us ${ }^{5}$. As we anticipated, considerable time and effort was required before starting our interviews in order to secure the family's permissions to participate, and which followed the Federally mandated University Human Subjects Review Board protocols of confidentiality, voluntary participation, etc., and to fully explain the purpose for wishing to work intensively with the family; why it was important; how it related to the earlier survey; and to provide the necessary reassurances that our entry into the home would not pose a threat or be prejudicial to their interests. Thus once respondents agreed to participate we felt that it was best to move ahead immediately. The fact that this was a follow-up visit from an earlier survey, and that we always came well prepared with details about their particular case, also appeared to have been important in gaining their support and participation-at least in most cases.

Each team comprised 4 - 6 researchers and was led by one of the local research project directors who had the authority to speak for the research team, and whose good faith and bone fides could be readily checked and substantiated $^{6}$. Two or three members of the team-those with extensive experience in interviewing conducted the main interview(s) and compiled the life course trajectory (see below). Other team members sought permission to make the architectural sketches, and take measurements and photographs, and were accompanied and shown the house by a responsible or adult family member. This also made it possible for some additional questions to be posed about the functions of each room, the sequence of construction, etc. Later, upon rejoining the main interview group, they were able to follow up with further questions to the home owner relating to the physical fabric of the dwelling, particular problems with the design and construction of the home, and the plans that the owners had for the future. Thus the process became very interactive between team participants and various household or family members. It also helped to widen the collection of case study materials away from a single respondent or the pair of household heads/principals.

In Mexico City and Monterrey all of the intensive case studies were undertaken over a ten day period, with later call backs by two team members to present each family with the two deliverables described earlier. In Guadalajara and Buenos Aires where some members of the team lived and worked, interviews were spread over several months and it was feasible for them to return and make several visits for each case, thereby following more closely the original strategy. Each primary visit to the case study site took between three and four hours to complete, and was followed immediately by an off-site 30 - 45 minute debriefing and group brainstorming about "what each of us had seen", and what we might learn and conclude from that particular case. It was extremely helpful to discuss the particular experience while it was fresh in our minds, not only because it allowed us all to contribute our ideas and impressions, but it also generated strong motivation and momentum for us to follow through and start building that particular case study archive. The "exit" discussion was tape recorded, and became the basis for the summary findings included under section 13 of the final base document template created for each family (see Appendix).

Each member of the team was assigned one or more of the following tasks: writing up the interviews; making a first draft of the family tree; preparing clean measurement diagrams from which to work subsequently; making a plan of the house construction sequence over time; archiving the photos tied to the dwelling structure, etc. In order to ensure that no records were lost, we made digital photographs of all draft diagrams and field sketches. All of the materials, interview tape recordings, notes and photos were stored according to a common agreed archival structure.

\section{Training, Preparation and Application of the Methods and Instruments}

Adequate preparation is essential for all team members who participate in the various stages and elements of

\footnotetext{
${ }^{5}$ However, preparation of the plans took much longer, and was undertaken several months later in most cases. Fulfillment of the commitment was important and widely appreciated, not least since the plans came in hard copy and CD ROM, and comprised floor plans, three dimensional build-out diagrams with sectional photographs (see Figures 6-9).

${ }^{6} \mathrm{~A}$ letter was left with every household describing the project and provided the contact details of the local team.
} 
data collection, and we spent two full days in training which included role play interviewing. Two or three people were designated to actually conduct the interviews, with each person having a specific role: 1) the lead interviewer to conduct and develop the conversation; 2) a lead note taker and back-up interviewer to provide appropriate prompts and cross-check questions and requests for clarification; and 3) a lead person to draft the life and life history and dwelling trajectory and family tree (see below). Each team was fully briefed about each case beforehand, and had reviewed the original survey materials for each case (on household structure; family membership; form of land acquisition, etc.).

\subsection{Building the Base Document Template}

Not all sections in the basic template required completion in the same depth for each case study, although the data about the household membership, trajectory dynamics, and the dwelling plans were central to all cases, as was the final "take home" points learned (Appendix, section 13). The final case archive (folder) usually included a subfolder containing figures and photos that were too numerous to be included within the final case summary itself.

\subsection{Building the Life History Trajectory and Genealogy}

The creation of a social genealogy is an extremely effective instrument to understand the intersections between the biography and life history of the subject or case study household (Bertaux, 1996). But undertaking its construction requires skill and practice. Central to our preparation, therefore, was training about how best to construct the life history in order to prepare the family tree, and to explore the linkages between the household dynamic and the evolution of the dwelling (Figure 1). Role plays among team members helped us gain practice about how to build the genealogical sketch diagrams that would be later used to complete the genealogy and housing/household trajectories. As we quickly learned, this takes both skill and practice, and our role play efforts paid off as eventually we were able to make sketches in the field as tidy and accurate as that shown in Figure 2, and which would ultimately translate into the final "family tree" (Figure 3), mobility trajectories, and the addition and use of rooms.

Basically the method requires that the interviewer begin by penciling in the interviewee(s)' names in the center/top of the page (first generation) noting any previous marriages or families for either spouse/partner (although this was usually only noted briefly as a matter of record, and because it was sometimes a sensitive issue.

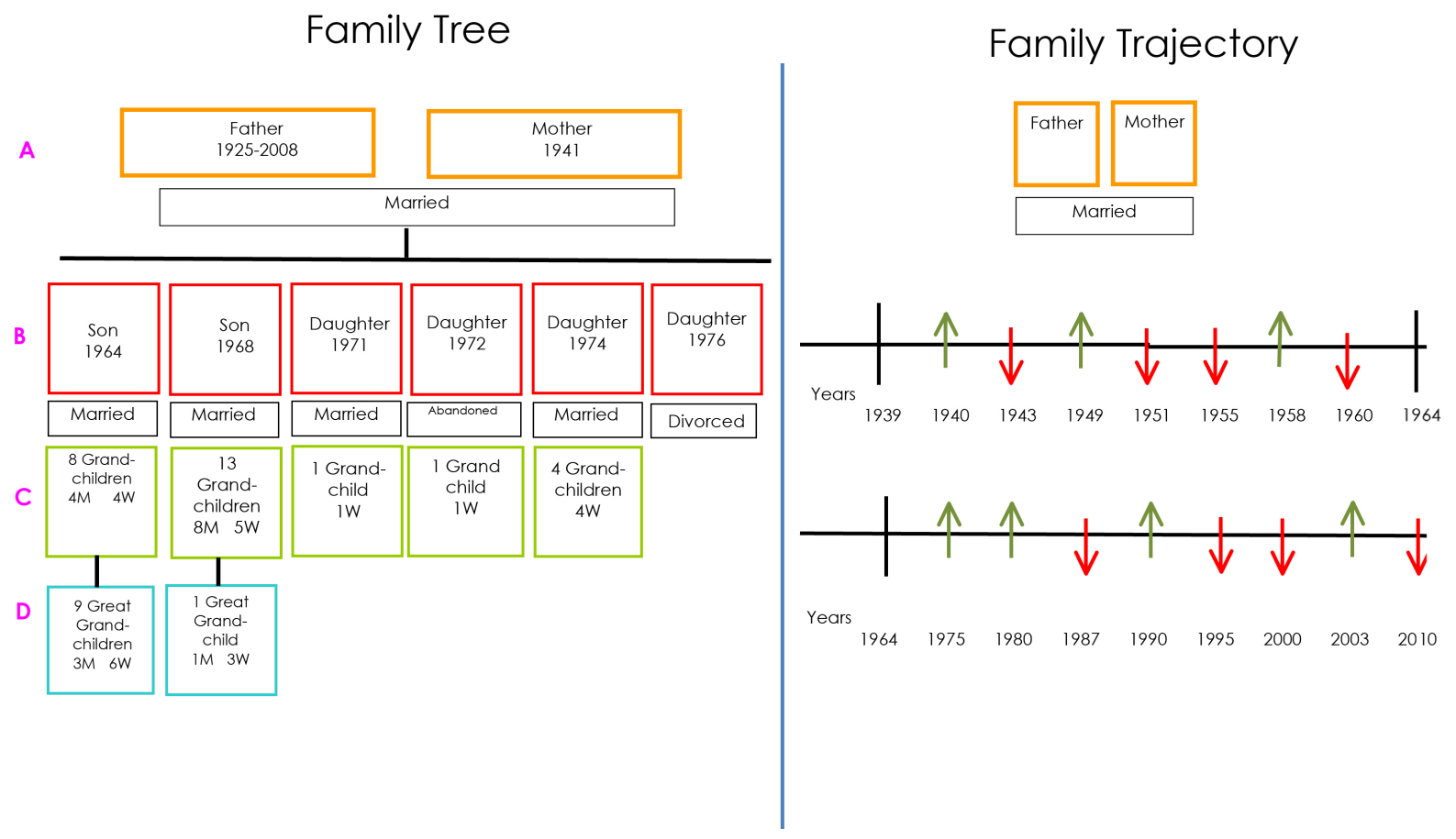

Figure 1. Structure of data collection Genealogy \& Trajectory. 


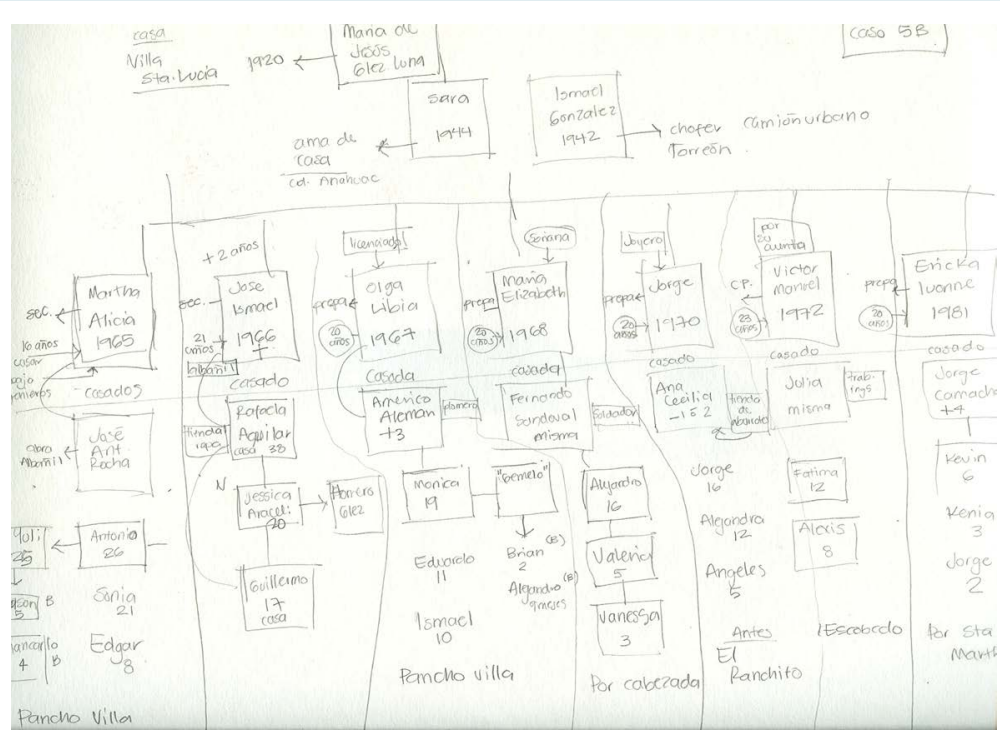

Figure 2. Photo of the fieldwork sketch used to document the family genealogy.

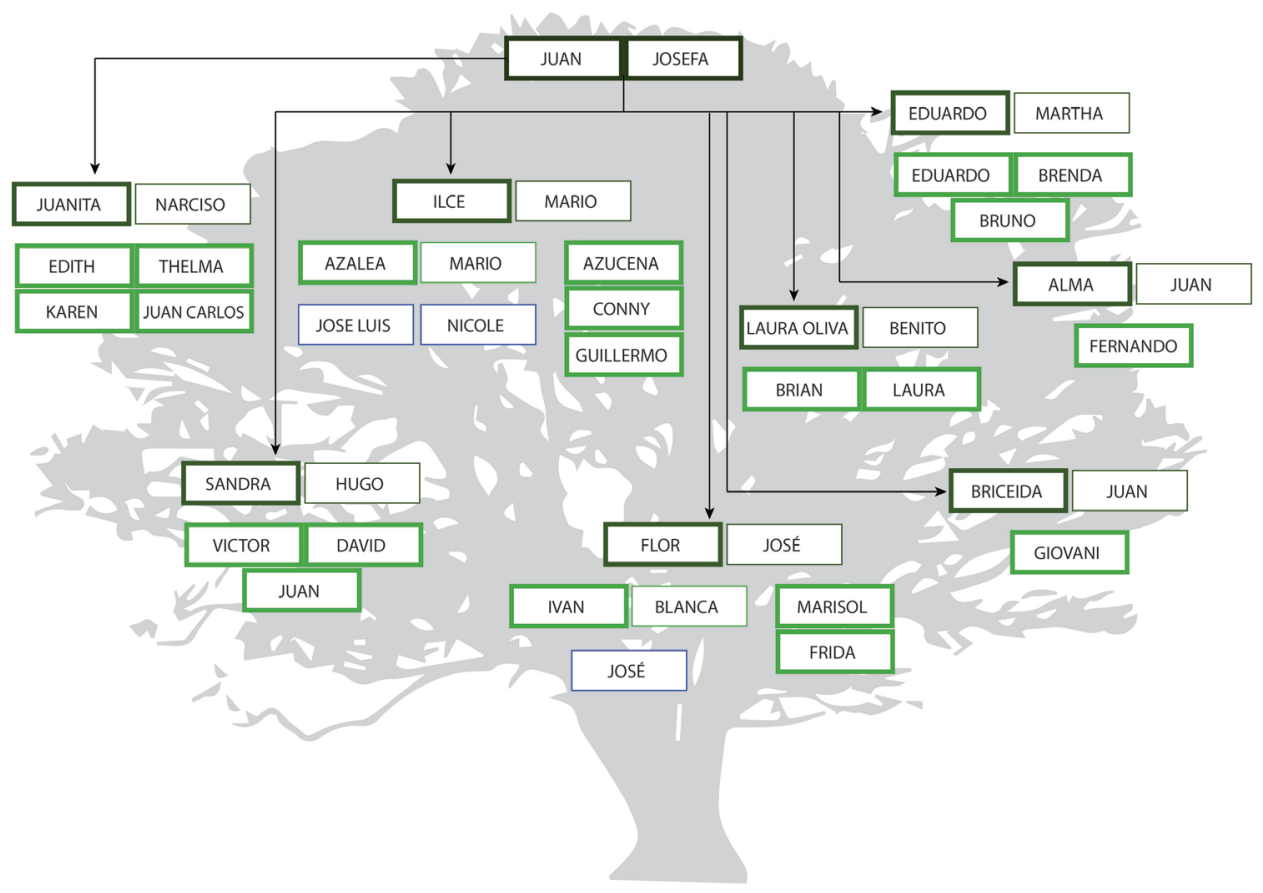

Figure 3. Example of a family tree.

Additional details were only solicited later once the genealogy was completed). Next, (see Figure 1 \& Figure 2) and what is a relatively straightforward exercise, was to build the second level noting each child's name, sex, birth date, education/work status, and if appropriate, their marital/household status, simultaneously noting the name of their partner/spouse. Once completed, we moved to the third level (grandkids), noting names and ages of their children, and if relevant, their current marital status, current place of residence, etc. While the structure we adopted for each case closely followed the template, it was left to the team members to actual design the "Family Tree" that would eventually be delivered to the family several weeks later (Figure 3).

Once the genealogy was drafted, a similar sequencing is used to develop the time lines and develop the trajectories and status of each household member starting with the arrival to the lot of the pioneer family (see Figure 1, right hand section), where each they lived now (on site or elsewhere), when they left home (exits, 
marked in red in Figure 1 \& Figure 4); re-entries (where applicable marked in green); and where they continued living on site, to collect details about their particular residential status (rooms occupied, cooking arrangements, etc.). Understanding the family biography is the key to understand the changes that occurred and the "tipping points" that appear to have produced them (Sautu, 2004: p. 49). For example, in our cases we were interested to identify births and deaths, exit and (sometimes) re-entry points of family and household members (Figure 1 \& Figure 4), all of which were critical to understanding how the family dynamics and life course data intersected with room construction and house extensions, and allocation of space to individual family members, or to households.

Next, and after these household change materials are completed, one can begin to construct the timeline of the build-out of the lot, starting at the point of with arrival and first year (first and subsequent house structure details, etc.). However, rather than try to get a full year-on-year trajectory of self-help dwelling construction and extension (which we thought would be overkill), we decided to take three or four cross sections that were tied to major extensions or remodeling, or to important family history events such as the entry \& exits of key family members, separations \& deaths; subdivisions of the lot and dwelling arrangements; household dynamics and splitting/creation of new households, etc. These snapshots usually comprised the residential arrangements in the early years of occupancy and family building; the current situation, and then to circle back to one or two intermediate snapshot years that seemed especially important—a significant extension, building a second floor, the creation of a separate housing unit for an adult child, etc.

\subsection{Preparing the House Plans, and Build-out Diagrams}

Constructing the house plans is relatively straightforward especially for those with a basic training in geography or architecture. Nevertheless, it should be noted that when drawing up plans for informally self-built housing, the walls are often neither straight nor true (vertically or horizontally), so it is often impossible to accurately "square" the general measurements of each side of the house or individual rooms. These data collection are most efficiently carried out by two or ideally three people: two working the tape or measuring laser, a third person recording the dimensions and makes a rough sketch on a pad (Figure 5). Supplementary information is gathered along the way noting: 1) room function, 2) whose room, 3) when constructed, 4) apparent subsequent modifications made, and 5) observations about particular problems (such as dampness or exposed wiring), etc. For our purposes this sub-team also gathered information about the structural problems of the house and possible rehab and renovation needs. Afterwards, the rough sketches generated on site would be drawn-up more neatly and later provided the basis for the eventual architectonic plans and three dimensional renderings of the dwelling development over time (Figures 6-9).

\subsection{Building the Final Case Study Folder Archive}

A single directory folder was created for each case study, with separate subfolders containing information on each family, digital audios of the interviews, house plans, chronology of housing build out on the lot, and an identification of construction problems for that dwelling; the final integrated household case study draft document; and a folder of digital photos. Several of these folders contained jpeg images of field sketches as a precaution against any loss of materials (especially important when working in teams with materials being sent to different locations for final elaboration).

\section{Insights Gained from Using Intensive Case Study Approaches}

It is not possible to provide detailed examples of the many insights that were gained through the application of this in depth intensive case study methodology, but we do wish to give a sense of a number of findings and insights that we gained, as well as new propositions that we began to formulate that, with further research, could form the basis for developing grounded theory about family life course and housing production and consumption associated with self-building among low income households.

For example the case studies provided a much more nuanced understanding of the symbolic value of home for first and second generation family members. We knew that once owners had gained a foothold in the land market and begun to self-build their homes successfully then most were unlikely to move again—in Alan Gilbert's (Gilbert, 1999) words "a home is forever" and that an important element was always to create a patrimony to leave to one's children (Ward, 2012). With the case studies we got a more full appreciation of the symbolic val- 

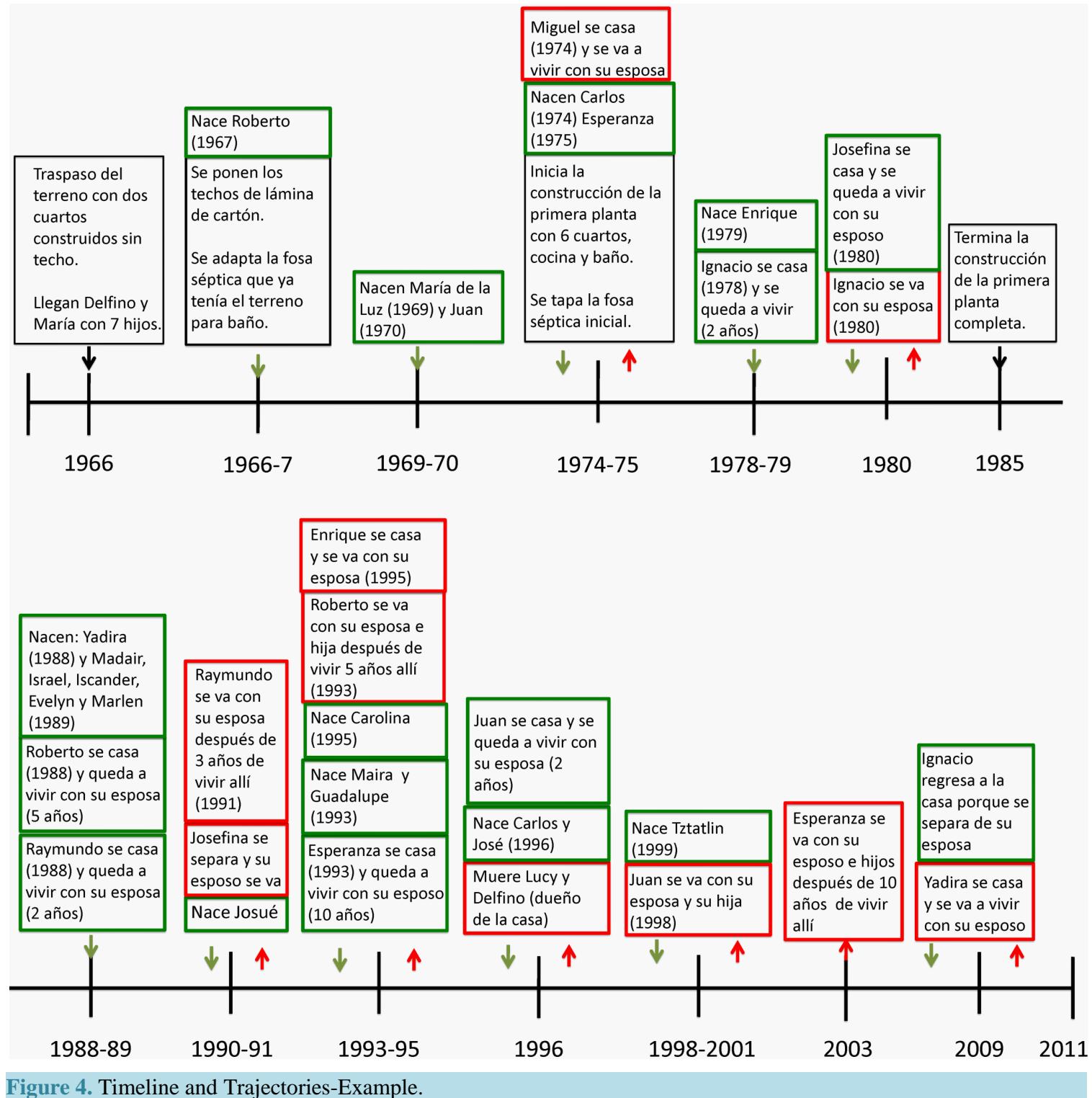

ues that families imbue to the family home. For original owners it was invariably a sense of pride and achievement in the asset that they had created, forged through their own sweat equity often at considerable social costs and hardships. For many of the children and grandchildren, too, the family home continued to represent an important anchor point and place to which they returned at weekends and for family reunions at least as long as one or more parents were still alive. Some expected to become owners or part owners and to move back into the home after their parents passed away.

However, it became apparent that not everyone had such positive sentiments about the home. Adult children who had successfully set up on their own sometimes expressed little intention of living there or maintaining it as a space for family reunions-much to the dismay and disappointment of their parents. Also, not all owners or elderly heads want the home to be "forever": in one particular case in Mexico City the matriarch (whose husband had long since died) expressed her wish to sell up and move back to live her last years in her pueblo. She was tired and fed up with having to cater to so many children and grandchildren: so much so that she wanted to sell the house. However, her eldest daughter insisted that the house really belonged to her and her siblings, and that she and her father's efforts to build-out the home gave her the expectation and right as de facto owner! The mother was not going anywhere soon. Understandably this was a tense interview and exchange during which mother and daughter went back and forth on the subject. 


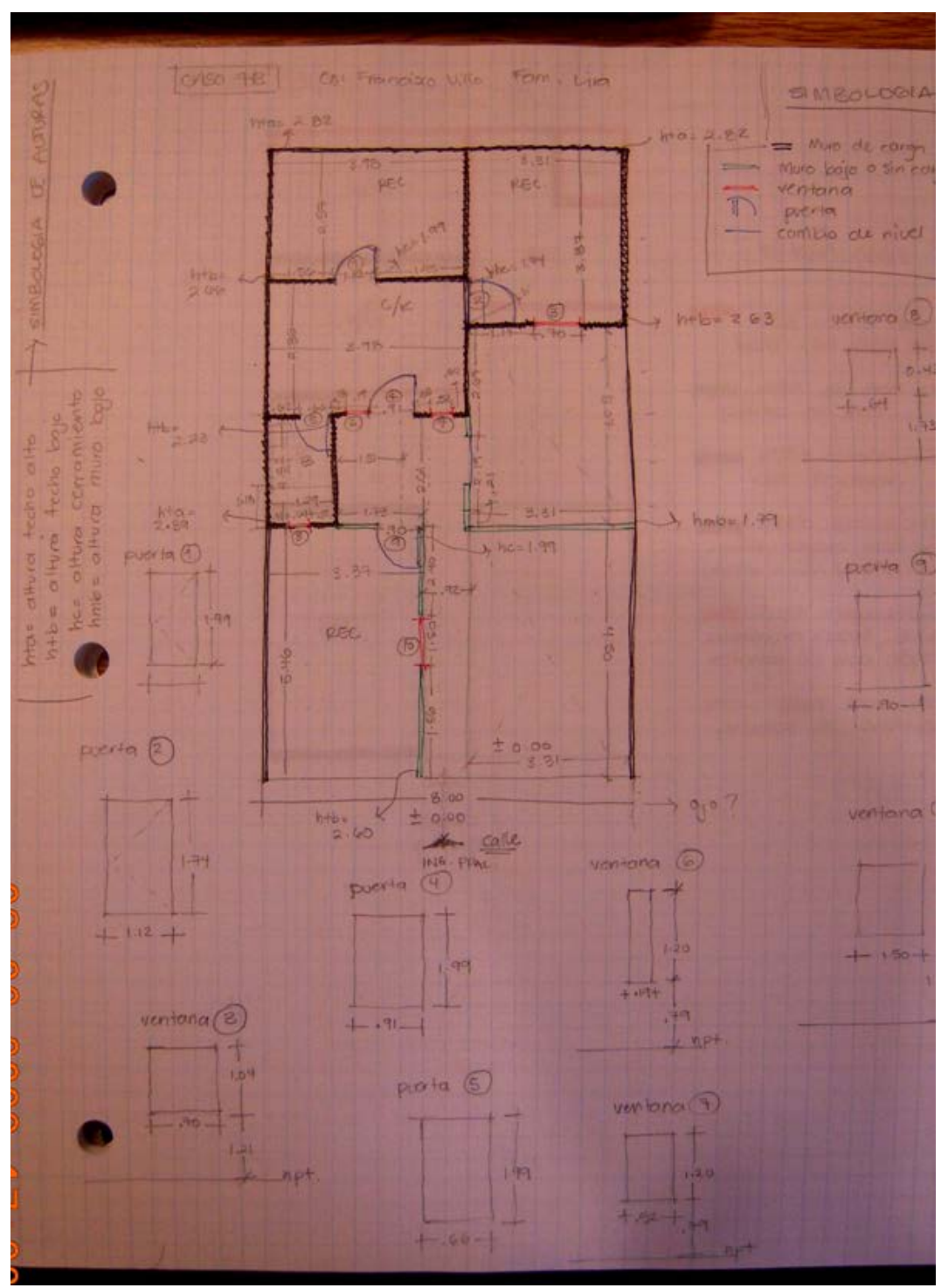

Figure 5. Photo of the fieldwork sketch plan with dwelling measurements and notations.

Other rich insights also presented themselves about inheritance and succession upon which we have reported elsewhere (Grajeda \& Ward, 2012). And while we always anticipated the likelihood of conflicts between siblings downstream, we were not prepared for the many different interpretations and constructions about who had the primary rights of inheritance: male heirs, eldest son, youngest daughter, unmarried children, incapacitated children or family members etc. Moreover, few were willing to countenance children born from other marriages or from extramarital affairs. Often these informal expectations were implicitly agreed while the parent(s) were still alive, but we do wonder how far they will ultimately be adhered to once both parents have passed away, although consensus was usually apparent where there was a need to protect a disabled or retarded adult sibling.

The household trajectories taught us that there is much more "churn" than we had ever anticipated. We began to see quite clearly the intersection and interrelationship between the life course of members of the household, the nature of household organization over time, the motivations of household members for exit and (often) reentry and the decisions that adults undertook regarding dwelling use and extensions. The dwelling evolved in close association with the family trajectory and was rarely, if ever, static: the number of rooms, their use and levels of finishing out were all highly dynamic and changed iteratively with the life course of the members of the household(s). 


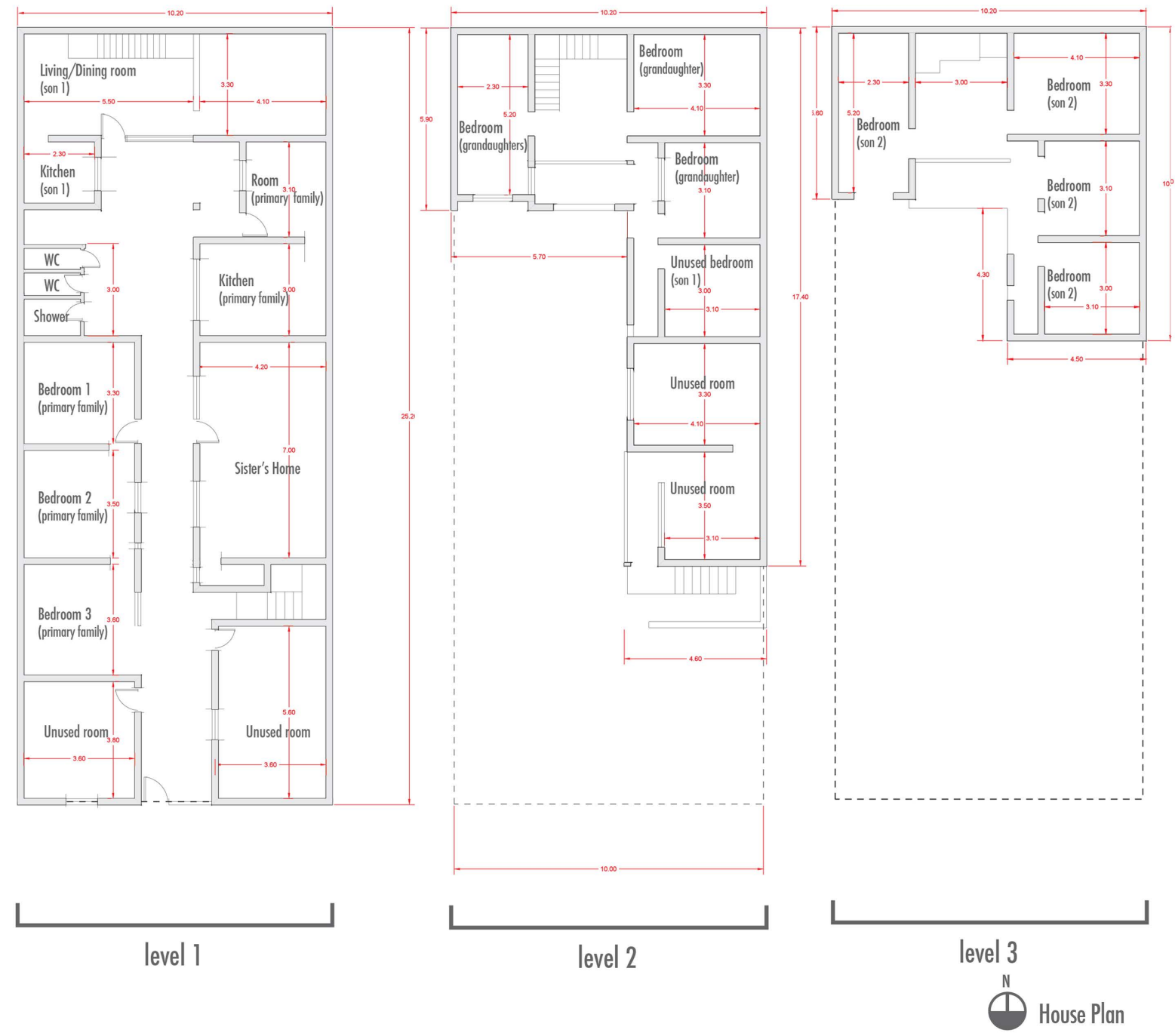

Figure 6. Cleaned-up house plans. Case \# 4, (in Colonia Isidro Fabela, Mexico City).

The prevailing idea on life-course mobility is that most children will leave the family house when they get married; one or two may remain in the family house; and that parents will stay in their self-built house until they die. What we found was a much more dynamic situation in which adult children exit (usually to set up their own households), but many return to share the lot with their own families living as a separate household, while others-divorced or separated-returned to the family home. Others left to work or moved to the USA but retained a stake in the home and returned periodically for months or years at a time. For many it was a bolt-hole to which they could, if necessary, readily return. One case that we fully documented in Guadalajara comprised a couple who lived with their children and other relatives. Over 46 years most of them had actually moved in and out of the main house several times. The couple had six children of their own, 30 grandchildren, and 13 great-grandchildren; while for Sr. Juan this was his fourth family and he had another fourteen children from three previous marriages and a child outside marriage. We estimate that as many as 74 people have lived in the main house at different times during the last four decades.

It was also apparent that in addition to the first generation parent owners who were often quite elderly, certain individuals in the family had much more influence in decision making about the home than others. The basis for that authority was interesting and most often appeared to be directly linked to the relative input and investment that an individual (or couple) had made over time (through actual building, financial support for the construction and services, or through sustaining and providing for other members). Even though some siblings and third generation children (grandchildren, nephews and nieces, etc.), had free use of the dwelling and patio, it became ob- 


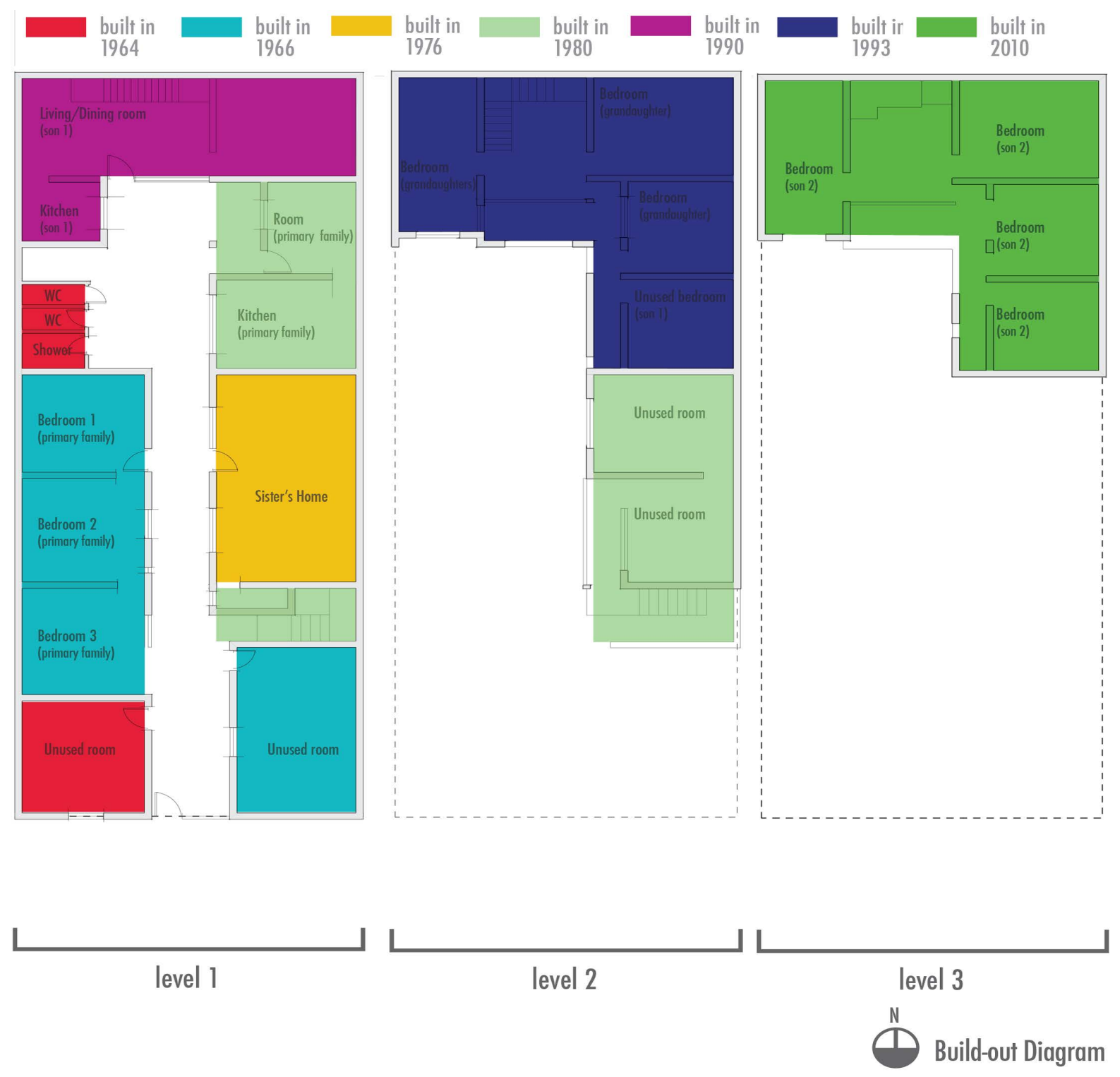

Figure 7. Build out plans and room usage, (case \# 4. Colonia Isidro Fabela, Mexico City).

vious that one or two individuals had implicit aegis over the management and "ownership". Invariably they were also the person to whom we were directed for permission to conduct the case study.

In terms of the physical structure and current living conditions, we also learned to question our assumptions about what good and bad housing conditions meant for the people we interviewed and with whom we interacted. Maybe because many of them had lived many years in the home, or because of the notion that they could not afford to be picky, we found few family or household members complained about the poor standard of the dwelling, or the lack of privacy and anachronistic aspects of the dwelling arrangements and current needs. Owners and family members would recognize and prioritize problems associated with leaky roofs, subsidence or flooding, but rarely would problematize cramped or inadequate bathroom and toilet facilities, lack of privacy, or poor air quality, etc., and to the extent that they were openly critical of their residential environment this mostly related to external threats-flooding, local gangs and anti-social behavior of neighbors etc. This is not to say that such in-house problems do not exist, or that these should not form part of future rehab and housing renovation that we analyze and describe elsewhere (Ward, Jiménez, \& Di Virgilio, 2014), but it did alert us to take care in ascribing particular models or proposals for rehab—such as that of larger and better equipped bathrooms for ex- 


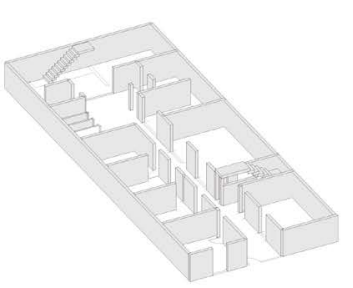

Level 1

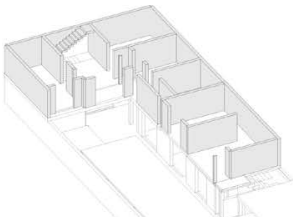

Level 2

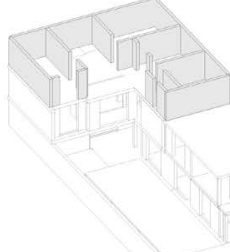

Level 3

3D Build-out Diagram

Figure 8. Example of build out in 3-D, (case \# 4. Colonia Isidro Fabela, Mexico City).

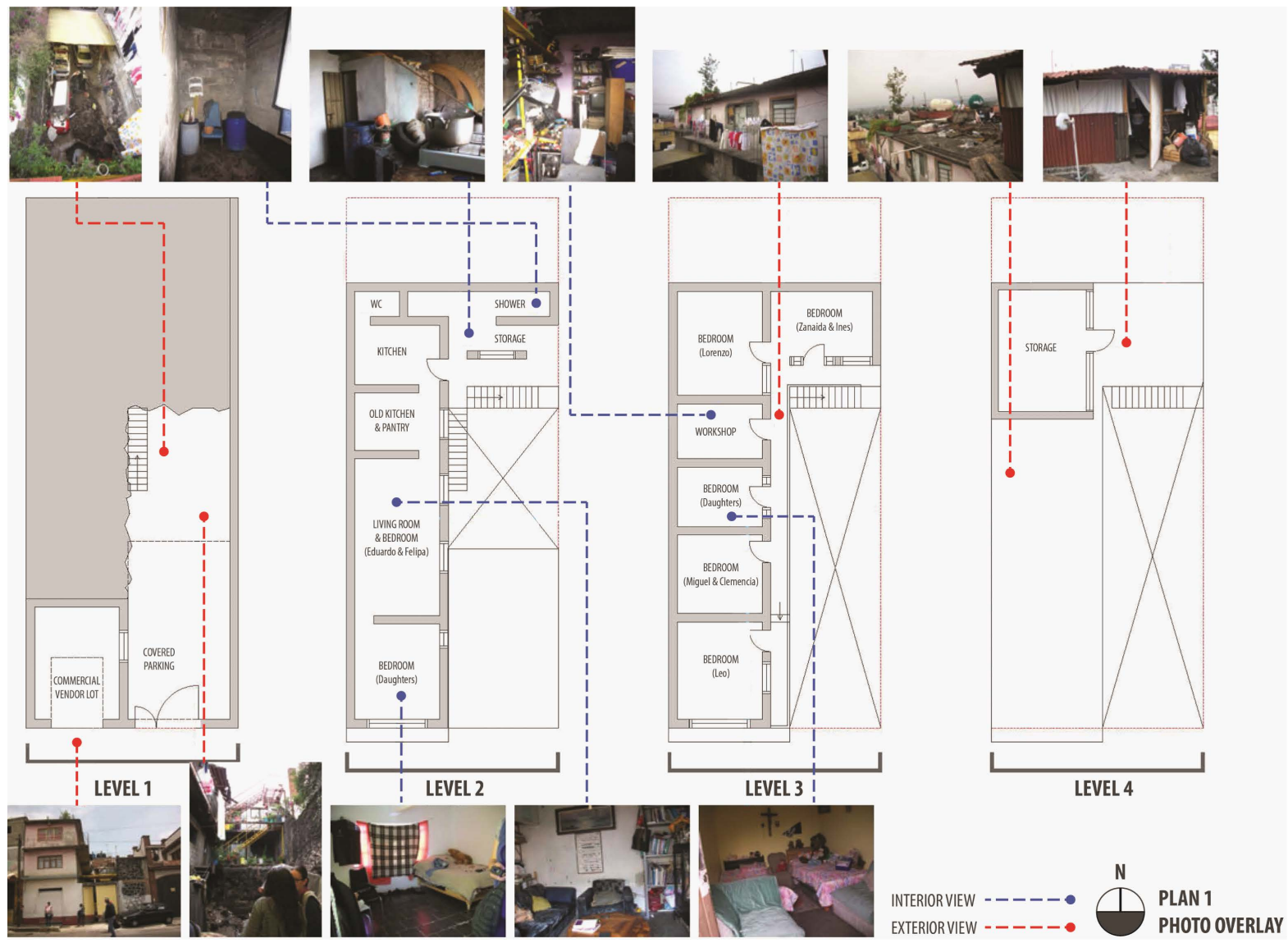

Figure 9. Example house building plans \& photos, (case \# 7, Isidro Fabela, Mexico City).

ample, which from our perspective, cried out for improvement but which were rarely prioritized by the families themselves.

\section{Concluding Thoughts}

We believe that the methodology that we offer here provides an innovative and replicable contribution about how to generate and use intensive case studies within broader mixed-method research. We know of no other multidisciplinary studies involving sociologists, anthropologists, geographers, and architects/urban designers that have interleaved macro-level surveys and multi-dimensional intensive case studies in quite the same way, applying (and sometimes modifying), the strategy and techniques in multiple city fieldwork locations. However, undertaking intensive case studies such as those described here is time-consuming: we estimate that over 60 
person hours was rendered in completing each case study from start to completion of the case study folder and the final presentation of the deliverables to the families. The question arises: was it worth the effort? We believe that it was. Without this experience and level of detail we would never have "seen" a number of important findings that ultimately have helped to shape our final research products (Ward, Jiménez, \& Di Virgilio, 2014). However, although efficient, it was also extremely hard work, and it was costly in terms of time, effort and resources.

For those coordinating the research there are considerable managerial and organizational challenges: getting a team of several members safely in and out of the field; keeping them together and focused on immediate follow-through; storing and archiving the materials at different stages of elaboration; ensuring access to all personnel as they needed them. In this respect the Monterrey and Mexico City team experience was different from either Guadalajara or Buenos Aires, given that most of the team did not reside and work locally. In both Monterrey and Mexico City, we were a research team working intensively and away from home over a short period of two weeks (in each), which allowed us to complete the fieldwork in a relatively short time span. And while the downside in Guadalajara was that the collection of these materials spread over several months, the advantage was that they were able to develop a closer and ongoing rapport with particular households, and to engage in a more genuinely multiple-visit strategy. Both modes of data collection were highly instructive and successful, although we believe that the longer period of interaction with respondents in Guadalajara and Buenos Aires offered a more complete and satisfactory experience, both for the research team, and almost certainly for the case study families themselves.

\section{Acknowledgements}

Peter Ward wishes to acknowledge the generous funding support for the elaboration and testing of this methodology from: the Policy Research Institute of the LBJ School of Public Affairs, and the Andrew Mellon Summer Faculty Research Awards from the Lozano Long Institute of Latin American Studies at the University of Texas at Austin. Jointly, the authors are also grateful to the following doctoral students who assisted in developing different parts of the methodology and preparation of the figures: Elizabeth Padilla Etienne, Erika Grajeda \& Edna Ledesma.

\section{References}

Bertaux, D. (1996). Historia de casos de familia como método para la investigación de la pobreza. Buenos Aires: Revista Sociedad, Cultura y Política.

Berube, A., Lang, R. E., \& Katz, B. (2005). Redefining Urban and Suburban America. Washington DC: Brookings Institution.

Coleman, J. S. (1988). Social Capital and the Creation of Human Capital. Journal of Sociology, 94, 95-120.

Creswell, J. (2013). Qualitative Inquiry and Research Design: Choosing among Five Approaches (3rd ed). Thousand Oaks, CA: Sage.

Dunning, T. (2012). Natural Experiments in the Social Sciences: A Design-Based Approach. Cambridge: Cambridge University Press.

Durst, N. \& Ward, P. M. (2014). Measuring Self-Help Home Improvements in Texas Colonias: A Ten Year Snapshot Study. Urban Studies, 51, 2141-2157. http://usj.sagepub.com/content/early/2013/11/20/0042098013506062

Gans, H. (1962). The Urban Villagers. New York: The Free Press.

Gilbert A. (1999). A Home Is Forever? Residential Mobility and Homeownership in Self Help Settlements. Environment and Planning. 31, 1073-1091 http://dx.doi.org/10.1068/a311073

Gilbert, A. (1996). The Mega-City in Latin America. New York: United Nations University Press.

Gilbert, A., \& Ward, P. (1985). Housing, the State and the Poor: Policy and Practice in Three Latin American Cities. Cambridge: Cambridge University Press.

González de la Rocha, M. (1994). The Resources of Poverty. Women and Survival in a Mexican City. Blackwell: Oxford.

Grajeda, E., \& Ward, P. M. (2012). Inheritance and Succession in Informal settlements of Latin American Cities: A Mexican Case Study. Latin American Research Review, 47, 138-162.

Leacock, E., (1971). The Culture of Poverty: A Critique. New York: Simon and Schuster.

Lewis, O. (1961). Five Families: Mexican Case Study in the Culture of Poverty. New York: Random House. 
Lewis, O. (1968). A Study of Slum Culture: Backgrounds for La Vida. New York: Random House.

Menéndez, E. (1992). Grupo doméstico y proceso salud/enfermedad/atención. Del “teoricismo” al movimiento continuo. En Cuadernos Médico Sociales, 59, 3-18. Rosario: Centro de Estudios Sanitarios y Sociales.

Portes, A. (1972). Rationality in the Slum: An Essay in Interpretive Sociology. Comparative Studies in Society and History, 14, 268-286. http://dx.doi.org/10.1017/S001041750000668X

Putnam, R. (1993). Making Democracy Work: Civic Traditions in Modern Italy. Princeton, NJ: Princeton University Press.

Safa, H. (1970). The Poor Are Like Everyone Else, Oscar. Psychology Today, 4, 26-32.

Sautu, R. (2004). El método biográfico. La Reconstrucción de la sociedad a partir del testimonio de los actores. Buenos Aires: Lumiere.

Stake, R. (1995). The Art of Case Study Research. Thousand Oaks, CA: Sage Publications.

Suttles, G. (1974). The Social Order of the Slum: Ethnicity and Territory in the Inner City. Chicago, IL: University of Chicago Press.

UN-Habitat (2003). The Challenge of Slums. Global Report on Human Settlements. United Nations Human Settlements Programme, Earthscan Publications Ltd., London and Sterling.

UN-Habitat (2006). State of the World's Cities 2006/7. The Millennium, Development Goals and Urban Sustainability: 30 Years Shaping the Habitat Agenda, United Nations Human Settlements Programme, Earthscan Publications Ltd., London and Sterling.

Valentine, C. A. (1968). Culture and Poverty: Critique and Counter-Proposals. Chicago, IL: University of Chicago Press.

Varley, A. (1994). Housing the Household, Holding the House. In G. Jones, \& P. Ward (Eds.), Methodology for Land and Housing Market Analysis (pp. 120-134). Cambridge, MA: Lincoln Institute of Land Policy.

Ward, P. M. (2012). “A Patrimony for the Children”: Low-Income Homeownership and Housing (Im)Mobility in Latin American Cities. Annals of the Association of American Geographers, 102, 1489-1510. http://dx.doi.org/10.1080/00045608.2011.628260

Ward, P. M., Jiménez, E., \& Di Virgilio, M. (2014). Housing Policy in Latin American Cities: A New Generation of Strategies and Approaches for 2016 UN-HABITAT III. London: Routledge.

Young, M. and Willmott, P. (1957). Family and Kinship in East London. London: Routledge and Keegan Paul. 


\section{Appendix: Final Template for the Elaboration of Comparative Case Studies}

\section{Criterios de la selección del caso de estudio y qué es lo interesante}

Escribir un título breve que describa el caso (Por ejemplo: intestado y resolución de la situación por la vía legal, etc.).

Describir en máximo, una página, el resumen del estudio de caso. Sin detalles.

\section{Metadata}

1) Ciudad, Nombre del Asentamiento, Dirección, Número del cuestionario de origen, código de referencia, Nombre de los dueños fundadores.

(Nota importante: Esta información será removida antes de enviar a la Universidad de Texas, por cuestiones de confidencialidad. Las únicas personas que deben quedarse con esta información son los responsables del proyecto en cada ciudad. Por lo tanto la seguridad de la información radica en los responsables).

2) Cuadro resumen del número de visitas, fecha, tiempo que se llevó, con quién se hizo la entrevista, quién hizo la entrevista, señalar si se utilizó otra técnica para obtener la información, además de la entrevista semi-estructurada.

3) Calidad de la entrevista. Qué tan dispuesta estuvo la gente, etc. Anotar, observaciones metodológicas (qué dio resultado para obtener información, qué obstaculizó, recomendaciones para próximos trabajos). Indicar dificultades o problemas con la entrevista o con el levantamiento.

3. Reconstrucción de los dueños fundadores y las personas que vivieron en la casa de acuerdo con el árbol genealógico (formato)

1) Situación actual detallada: Tamaño del hogar y número, estructura, etc.

2) Situación cuando llegaron al lote (en detalle).

3) Cambios en la estructura familiar a lo largo del tiempo (Síntesis).

Mostrar la expansión de la familia y cambios en la estructura familiar (nuclear a extendida, casamientos segunda generación), Crisis familiares (muertes, separaciones, divorcios).

4. Levantamiento de la vivienda, su relación con la trayectoria familiar, financiamiento de construcción o modificaciones y problemas constructivos

1) Plano arquitectónico de 3 etapas de construcción de la vivienda (o solo dos si se trata de un traspaso reciente-al llegar y ahora). Presentar los dibujos arquitectónicos de acuerdo con el formato: plantas, fachada, un corte, un esquema tridimensional, volumétrico. Fotografías de los tres, si fuera posible.

a). Situación Actual.

b). Situación Inicial.

c). Situación intermedia.

2) Vincular la vivienda con la reconstrucción de la trayectoria familiar (al menos en los 3 horizontes). A lo largo del tiempo, quién ha utilizado cada cuarto. Registrar los cambios y la razón por la que se dieron. Por ejemplo cambio en el número de hogares (casamientos), salida y entradas, es decir, cambios en la estructura familiar. Incluir de forma gráfica en el momento actual, quién usa cada espacio y para qué.

3) Fuentes de financiamiento, para construir o remodelar diferentes partes de la vivienda, estrategias, etc.

4) Cuadro según formato, de los problemas constructivos, de funcionamiento, y de otro tipo (que no les guste algo) que presente la vivienda. En el cuadro señalar quiénes en la casa reportan qué problema. Aquí incluir las fotografías. En caso de que sea pertinente, hacer en un cuadro o en un plano arquitectónico, las propuestas de solución. Tomar fotografías que ilustren los problemas.

5) Un párrafo, ilustrado con fotografías, si fuera relevante, de los elementos simbólicos o simplemente, cuestiones que no les gustaría cambiar para nada y por qué. (Por ejemplo, el árbol que plantaron en el terreno cuando llegaron, el piso que construyeron con tanta dificultad de material reciclado de demoliciones en la ciudad).

IMPORTANTE:

Los puntos 5 - 8 se llenarán sólo si son pertinentes para el caso que se está reportando. Por ello, se espera que sólo uno o dos puntos se contesten de manera detallada. Si hay información sobre más puntos, serán respondidos con menor detalle. Asegurarse de llenar en todos los casos el punto 9, referente a la discusión y conclusión sobre el tema central.

5. Movilidad de los dueños fundadores y sus dependientes

Reconstruir la trayectoria de vida de (el/la) los dueños fundadores, de acuerdo con el formato. Anotando los 
años clave, con datos de dónde provienen, Cuando se casaron, (si es pareja), a dónde se fueron a vivir, entradas y salidas de la casa, de los dueños fundadores y sus dependientes. Indicar las razones para quedarse, para irse y para regresar. Miembros de la familia extendida, quiénes llegaron (relación de parentesco, cuánto duraron, razones para irse y quedarse, eran parejas con hijos).

6. Actividad económica, estrategias en la vivienda para generar ingresos (actividades económicas o renta de alguna parte de la casa), etc. Cambios en el tiempo.

7. Título de propiedad/proceso/Cambios en el tiempo.

8. Cuestiones del testamento, herencia, sucesión. Conflictos, cómo surgieron, cuándo, quienes son los interesados, problemas, arreglos. Expectativas de los miembros de la familia.

9. Estructura de la vivienda y fuentes de financiamiento: para la construcción, el mantenimiento y las mejoras.

10. Percepciones sobre su colonia. Construcción de identidad a través de las 3 generaciones (o las que haya en la/s viviendas (si es el caso, diferenciar entre la identidad de los migrantes y nativos).

11. Necesidades especiales (trato a los viejos, abuelas cuidando nietos, discapacitados, etc.)

12. Citas, citables para los diferentes temas que no se hayan incluido en los temas tratados en esta ficha.

13. Resumen de hallazgos, referentes principalmente a las razones por las cuales se seleccionó el caso.

Responsible for Template: Jiménez, Ward and Di Virgilio, July 132009. 
Scientific Research Publishing (SCIRP) is one of the largest Open Access journal publishers. It is currently publishing more than 200 open access, online, peer-reviewed journals covering a wide range of academic disciplines. SCIRP serves the worldwide academic communities and contributes to the progress and application of science with its publication.

Other selected journals from SCIRP are listed as below. Submit your manuscript to us via either submit@scirp.org or Online Submission Portal.
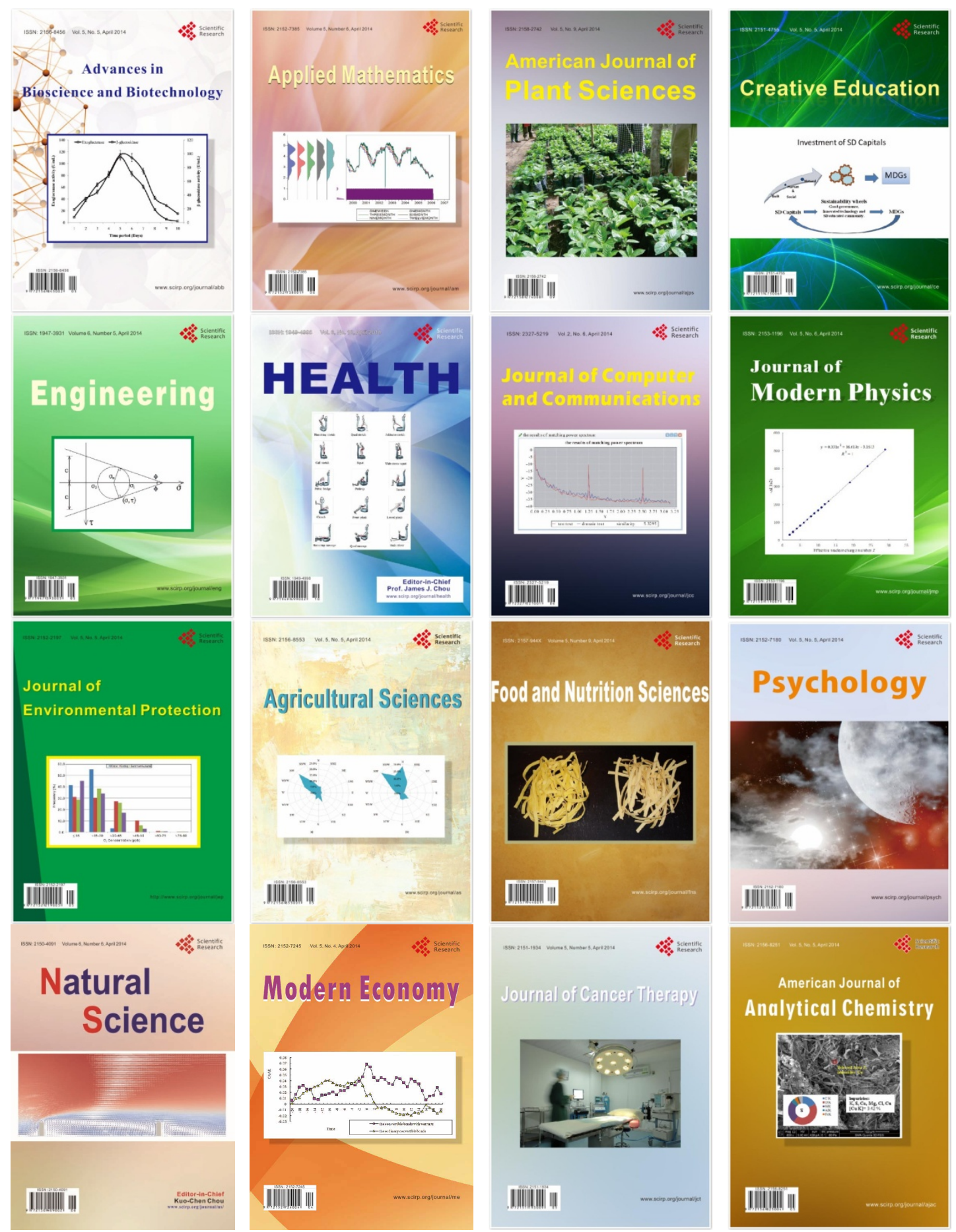